\title{
ARTIKELEN
}

\author{
THEMA
}

\section{Decentraal rekenkameronderzoek in Nederland: een overzicht ${ }^{*}$}

Klaartje Peters \& Sabine van Zuydam

Gemeenten en provincies hebben sinds ongeveer twintig jaar verplicht een rekenkamer of rekenkamerfunctie. Hoe werkt het rekenkamerinstrument nu en welke bijdrage levert het aan het decentraal bestuur? Dat is de vraag die in dit artikel centraal staat. Daartoe zetten we de beschikbare kennis over rekenkamer(commissie)s op een rij en presenteren we de resultaten van een eigen analyse van de opbrengst van drie jaar gemeentelijk rekenkameronderzoek. We stellen vast dat in het overgrote deel van de gemeenten en in alle provincies de rekenkamer(commissie) inmiddels geïnstitutionaliseerd. Steeds minder vaak hebben raadsleden daarin (ook) zitting en de output is licht toegenomen van circa 1 naar gemiddeld 1,5 onderzoek per jaar. Waar eerst vooral bedrijfsvoeringsonderwerpen werden onderzocht, heeft enige verbreding naar meer beleidsinhoudelijke thema's plaatsgevonden. Tegelijkertijd worden daadwerkelijke maatschappelijke effecten van beleid in rekenkameronderzoek weinig gemeten. Gemeenteraadsleden zijn behoorlijk tevreden over hun rekenkamer(commissie). Maar ze gebruiken rekenkamerrapporten weinig in het controleren van het college en ook aan de kaderstellende rol voegen rekenkamer(commissie)s weinig toe. Over de mate waarin rekenkameronderzoek in meer objectieve zin een bijdrage levert aan het gevoerde bestuur en versterking van het functioneren van de gemeenteraad is weinig bekend, wat dan ook een thema voor toekomstig onderzoek is.

Relevantie voor practitioners: dit artikel laat zien dat (a) het rekenkamerinstrument een vaste positie heeft verworven in het decentraal bestuur, (b) de productie van rekenkamer(commissie)s licht is toegenomen en de onderzoeksonderwerpen zich enigszins hebben verbreed, en (c) de bijdrage van rekenkameronderzoek aan het gevoerde bestuur lastig inzichtelijk te maken is. Enerzijds is er een behoorlijke tevredenheid, maar anderzijds zijn er signalen dat de uitkomsten weinig worden gebruikt.

* De auteurs bedanken Bob Smits en Tries van Trintelen voor hun belangrijke bijdrage aan de gegevensverzameling voor dit artikel, en Peter Castenmiller en Geerten Boogaard voor hun commentaar op een eerdere versie. 


\section{$1 \quad$ Inleiding}

Sinds 2005 kent elke provincie en sinds 2006 elke gemeente een wettelijk verplichte rekenkamer(functie) ter ondersteuning van de controlerende taak van de volksvertegenwoordiging, met als taakopdracht het onderzoeken van de doelmatigheid, doeltreffendheid en rechtmatigheid van het door het gemeente- of provinciebestuur gevoerde bestuur. ${ }^{1,2}$ Die taakopdracht, gecombineerd met het feit dat elke gemeente een eigen rekenkamer(functie) heeft, is in internationaal perspectief uniek (zie ook de bijdrage van Paul Hofstra in dit themanummer). Het rekenkamerinstrument kwam in de Gemeentewet en Provinciewet ${ }^{3}$ terecht als onderdeel van de dualisering, een operatie gebaseerd op het advies van de door de regering ingestelde Staatscommissie Dualisme en lokale democratie (commissieElzinga). Deze hervorming van het decentraal bestuur had tot doel om de taken en bevoegdheden van het college van B\&W en de gemeenteraad duidelijker van elkaar te scheiden. Het college moest vooral besturen, de raad moest daarvoor kaders stellen en het college controleren. Een rekenkamer zou de raad daarin kunnen ondersteunen en met name de controlerende functie kunnen versterken. Dezelfde redenering gold voor het provinciebestuur.

Wat weten we bijna twintig jaar later over de werking van dit instrument, en welke bijdrage het levert aan het decentraal bestuur? In wetenschappelijke zin is dat weinig. In Bestuurswetenschappen zijn door de jaren heen enkele artikelen over rekenkamers verschenen (Brandsen e.a., 2008; Smink, 2008; Castenmiller \& Albeda, 2009; Koster \& Tollenaar, 2017). Vakbladen op het gebied van audit \& control en toegepast beleidsonderzoek ${ }^{4}$ besteden met enige regelmaat aandacht aan rekenkamers. Het betreft dan vooral de werkwijzen in rekenkamer- en evaluatieonderzoek en de doorwerking ervan. Ook juristen hebben in de loop van de jaren af en toe over rekenkamers gepubliceerd (in bijvoorbeeld De Gemeentestem), met name over de bevoegdheden en de juridische status van dit nieuwe instrument.

In dit artikel zetten we de beschikbare kennis over decentrale rekenkamers ${ }^{5}$ op een rij. Ons uitgangspunt is daarbij steeds geweest de vraag welke bijdrage het instrument levert aan het lokaal bestuur, en het werk van de gemeenteraad in het

1 Ook diverse waterschappen hebben een rekenkamercommissie, al is het instrument voor waterschappen niet wettelijk verplicht. De laatste stand van zaken was dat 12 van de 21 waterschappen een rekenkamercommissie kennen (nvrr.nl - geraadpleegd op 27-1-2021). We laten de waterschapsrekenkamercommissies in dit artikel verder buiten beschouwing.

2 We spreken in dit artikel veelal van rekenkamers, waarmee we zowel rekenkamers als rekenkamercommissies bedoelen.

3 Gemeentewet: hoofdstuk IVa (art. 81a t/m 81o) en IVb (art. 81oa) en hoofdstuk XIa (art. 182 t/m 185); Provinciewet: hoofdstuk IVa (art. 79a t/m 79o) en IVb (art. 79p) en hoofdstuk XIa (art. $183 \mathrm{t} / \mathrm{m} \mathrm{186)}$.

4 Met name TPC (tijdschrift en online platform voor public governance, audit \& control) en Beleidsonderzoek Online.

5 We spreken in dit artikel veelal over gemeenten/gemeenteraden/colleges van B\&W. In de meeste gevallen worden daarmee ook provincies/provinciale staten/gedeputeerde staten bedoeld. 
bijzonder. Hierbij moet meteen de kanttekening worden gemaakt dat vooral kennis beschikbaar is over de output van rekenkamers. Over hun daadwerkelijke effect op het bestuur weten we minder. We voegen in het artikel nadrukkelijk ook kennis toe aan de bestaande literatuur. We hebben een analyse gemaakt van alle beschikbare gemeentelijke rekenkamerrapporten uit de jaren 2017, 2018 en 2019. Twee student-assistenten hebben in de zomer van 2020 alle websites van rekenkamers en gemeenten bezocht om de in die drie jaar gepubliceerde rapporten te downloaden. Voor gemeenten waarbij dit niet mogelijk bleek, is per mail contact gezocht met de rekenkamer zelf of met de griffie, om alsnog de gepubliceerde onderzoeksrapporten te verkrijgen. Als ook dat niet lukte, is telefonisch contact met hen gezocht. Uiteindelijk zijn in totaal 982 rekenkamerrapporten van 234 rekenkamers over 308 gemeenten verzameld.

De verzamelde onderzoeksrapporten zijn vervolgens door een student-assistent geanalyseerd en gecodeerd voor een aantal variabelen: titel, gemeentenaam, naam rekenkamer(commissie), vorm en samenstelling van de rekenkamer(commissie), het onderzochte onderwerp, de gebruikte onderzoeksmethoden en de focus van het onderzoek (doeltreffendheid, doelmatigheid en/of rechtmatigheid). Die laatste variabele is onderzocht door de rapporten te doorzoeken op het gebruik van de woorden 'doeltreffend(heid)', 'doelmatig(heid)' en 'rechtmatig(heid)'; daarbij is de context gecheckt om er zeker van te zijn dat het woord is gebruikt om de focus van het betreffende onderzoek te duiden.

Hieronder beschrijven we allereerst kort de beoogde functie van rekenkameronderzoek en de ontstaansgeschiedenis en ontwikkeling van de decentrale rekenkamers. Vervolgens schetsen we hoe rekenkameronderzoek invulling krijgt in gemeenten en provincies. Hierbij baseren we ons op eerder onderzoek, aangevuld met onze eigen verzamelde gegevens. Tot slot staan we stil bij wat er bekend is over het effect dat rekenkamer(commissie)s hebben op het openbaar bestuur en trekken we conclusies, inclusief een voorstel voor toekomstig onderzoek.

\section{Controle en verantwoording, en de democratische functie van rekenkameronderzoek}

Bij de voorbereiding van de dualisering van het gemeentebestuur en provinciebestuur zag de regering in navolging van de Staatscommissie hoe rekenkamers zouden kunnen bijdragen aan het lokaal en provinciaal bestuur. De memorie van toelichting bij de Wet dualisering gemeentebestuur noemt vier redenen voor het verplicht stellen van een lokale rekenkamer:

a De lokale rekenkamer versterkt de positie van de raad ten aanzien van de uitoefening van zijn controlerende functie.

b De aandacht voor en het belang van doelmatigheid en doeltreffendheid groeit - burgers beoordelen de overheid steeds meer hierop.

c Een verdere verbetering van de rechtmatigheids- en doelmatigheidstoets is gewenst. 
d De rapportages van de lokale rekenkamer vormen een goed aanknopingspunt voor het afleggen van rekenschap aan de burgers (Kamerstukken II 2000/01, 27751, nr. 3, p. 66).

Hieronder gaan we op die verschillende functies nader in. We voegen b en $c$ daarbij samen (in subparagraaf 2.3).

\subsection{Versterking controlerende functie van de gemeenteraad}

Het voornaamste doel van het verplichte rekenkamerinstrument is de versterking van de controle door de raad. De Staatscommissie constateerde dat de gemeenteraad het in de praktijk op allerlei manieren aflegde tegen het college van B\&W, en dat met name de volksvertegenwoordigende (agenderende) en de controlerende rol van de raad onvoldoende uit de verf kwamen (Staatscommissie, 2000; Denters e.a., 2000). Uit onderliggend onderzoek van de Staatscommissie onder raadsleden (Bakker e.a., 2000) bleek dat zij veel waarde hechtten aan die controlerende rol, maar volgens de commissie was dit in tegenspraak met 'de praktijk waarin dit in veel gemeenten van veel minder betekenis blijkt te zijn' (Staatscommissie, 2000: 103). De beschikbare controle-instrumenten werden relatief weinig gebruikt door het monistisch systeem, waarin wethouders deel uitmaakten van de raad (Staatscommissie, 2000).

In de memorie van toelichting gaat de regering expliciet in op de negatieve gevolgen hiervan voor de controle van het bestuur:

'Het huidige stelsel biedt te veel mogelijkheden voor het verschuiven van het politieke debat van openbare vergaderingen als die van raad en raadscommissies, naar de beslotenheid van collegevergaderingen en vergaderingen van collegefracties. Het behoeft geen betoog dat een dergelijk mechanisme een openbare controle en verantwoording niet ten goede komt.' (Kamerstukken II 2000/01, 27751, nr. 3, p. 23)

Hoewel het rekenkamerinstrument dus moet bijdragen aan versterking van de controle door de gemeenteraad, wordt uit de wet of de memorie van toelichting niet duidelijk wat die controle precies behelst, waar deze zich op moet richten of waartoe deze moet dienen. Het woord controle(ren) komt in de Gemeentewet alleen voor in relatie tot financieel beleid en financiële controle en de begroting en jaarrekening. ${ }^{6}$ Uit de memorie van toelichting wordt wel duidelijk dat rekenkamers vooral op doelmatigheid en doeltreffendheid moeten gaan toetsen, en in mindere mate ook op de rechtmatigheid van het bestuur. Controle achteraf op het collegebeleid zal bovendien, impliciet of expliciet, bijdragen aan 'inkadering van het toekomstige collegebeleid' (Kamerstukken II 2000/01, 27751, nr. 3, p. 50). Zo wordt indirect ook de kaderstellende functie van de raad versterkt. 


\subsection{Bijdrage aan publieke verantwoording}

Een tweede doel van het rekenkamerinstrument is volgens de memorie van toelichting een bijdrage aan het afleggen van rekenschap ofwel verantwoording aan burgers: 'De rekenkamer speelt een belangrijke rol bij de versterking van de controle van de raad op het college en meer in het algemeen bij de vormgeving van het concept van publieke verantwoording' (Kamerstukken II 2000/01, 27751, nr. 3, p. 46). Bestuurders kunnen publieke verantwoording afleggen door zich te verantwoorden in de volksvertegenwoordiging, maar ook op andere manieren.

In de literatuur over controle en verantwoording is dit een van de hoofdfuncties die standaard worden onderscheiden. Bovens e.a. (2008) noemen dit 'het democratische perspectief op verantwoording', Van der Knaap e.a. (2020) noemen het in hun handboek over beleidsevaluatie 'de democratische functie van evaluatie'. Van Montfort wijst er in zijn artikel over de start van de decentrale rekenkamers op dat deze functie van 'het transparant maken van het handelen en de prestaties van de gemeente' voor burgers de belangrijkste functie is van de rekenkamer (2003: 43).

De regering hecht dan ook zeer aan het onafhankelijke en openbare karakter van het rekenkameronderzoek (Kamerstukken II 2000/01, 27751, nr. A, p. 18). De memorie van toelichting stelt verder:

'Door deze grotere nadruk op onderzoek naar de doelmatigheid en doeltreffendheid van de besteding van publieke gelden wordt het proces van verantwoording versterkt. (...) Juist op deze manier dient de burger informatie te krijgen op grond waarvan hij kan beoordelen of hij «waar voor zijn geld» krijgt.' (Kamerstukken II 2000/01, 27751, nr. 3, p. 45)

Opvallend daarbij is de sterke nadruk op het argument van de besteding van publiek geld. Blijkbaar kijkt de regering vooral naar het nieuw te introduceren instrument als een rekenkamer.

\subsection{Bijdrage aan doelmatigheid, doeltreffendheid en rechtmatigheid van het bestuur}

Het derde doel van het nieuwe rekenkamerinstrument is het bijdragen aan de doelmatigheid, doeltreffendheid en rechtmatigheid van het gemeentebestuur. Het bewaken van de doeltreffendheid en doelmatigheid is volgens de memorie van toelichting weliswaar de verantwoordelijkheid van raad en college, maar de rekenkamer kan hier met deelonderzoeken op specifieke beleidsterreinen aan bijdragen (Kamerstukken II 2000/01, 27751, nr. 3, p. 46). In de memorie van toelichting wordt niet geëxpliciteerd hoe rekenkameronderzoeken hieraan kunnen bijdragen. Niet duidelijk is of bestuur en ambtelijke organisatie worden geacht direct te leren van de onderzoeken, of dat de bijdrage van het rekenkameronderzoek loopt via de gemeenteraad, die het college opdraagt er iets mee te doen. Haanemaayer (2012) stelt in dit verband dat het er vooral om gaat dat rekenkameronderzoek de aandacht voor doeltreffendheid en doelmatigheid bij gemeenten en provincies vergroot. 
De verantwoordingsliteratuur gaat uitgebreid in op de bijdrage die verantwoording kan leveren aan de verbetering van het functioneren van de overheid (Bovens e.a., 2008; Van der Knaap e.a., 2020). Het cruciale mechanisme daarbij is leren: doordat de verantwoording inzicht geeft in succes en falen en de oorzaken daarvan, kan geleerd en dus verbeterd worden. Benadrukt wordt daarbij overigens dat de openbaarheid en de nadruk op mogelijke sancties die horen bij verantwoording als democratische legitimatie moeilijk te verenigen zijn met de veilige en liefst besloten omgeving die nodig is om daadwerkelijk te leren van verantwoording (Bovens e.a., 2008; Jarvis, 2014).

\section{Decentrale rekenkamers: ontstaansgeschiedenis en ontwikkeling}

\subsection{Naar een rekenkamer voor elke gemeente en provincie}

De invoering van het dualisme aan het begin van deze eeuw verplichtte gemeenten en provincies tot de instelling van een rekenkamer(functie). Maar ook vóór die tijd bestonden er lokale en provinciale rekenkamers of varianten daarvan. Zo kenden diverse gemeenten en provincies zogenaamde rekeningcommissies en evaluatiecommissies van de gemeenteraad of provinciale staten, die de jaarrekening onderzochten of (beleids)evaluatieonderzoek verrichtten. In 2000 beschikte meer dan de helft van de 25 grote steden over een rekenkamerachtige voorziening, vaak samengesteld uit raadsleden (Staatscommissie, 2000: 254). In 2004 telde Steiner ongeveer 55 rekenkamers, rekeningcommissies en evaluatiecommissies op lokaal en provinciaal niveau (2004: 15).

De rekenkamerpraktijk in gemeenten en provincies kreeg een enorme impuls met de dualisering in respectievelijk 2002 en 2003. De Staatscommissie (2000) vond de ontwikkeling van een rekenkamerfunctie van groot belang voor de versterking van de controlerende rol van de gemeenteraad, maar had geadviseerd om de instelling ervan aan gemeenten zelf over te laten. De regering maakte daar in het voorstel voor de Wet dualisering gemeentebestuur een verplichte rekenkamer van. Dat stuitte op verzet. Onder druk van gemeentebestuurders voerde de VNG een succesvolle lobby tegen het verplichte karakter van decentrale rekenkamers. ${ }^{7}$ Dat zou een inbreuk vormen op de lokale autonomie en gevreesd werd voor de extra kosten van het inrichten en in stand houden van een rekenkamer. De parlementaire behandeling in 2001 leidde tot een amendement met een ter plekke verzonnen compromis, dat inhield dat gemeenten konden kiezen tussen een rekenkamer of een 'rekenkamerfunctie' (Castenmiller \& Peters, 2011). De Gemeentewet bood verder ook expliciet de mogelijkheid tot instelling van een gemeenschappelijke rekenkamer.

Ondanks scepsis bij een deel van de raadsleden en gemeentebestuurders, zeker in kleinere gemeenten, gingen gemeenten in de daaropvolgende jaren met het rekenkamerinstrument aan de slag (Wildeman, 2006; Van Montfort, 2003). Op

$7 \quad$ Het IPO ondersteunde de verplichte rekenkamer wel (memorie van toelichting Wet dualisering gemeentebestuur). 
1 januari 2006 hadden alle provincies en bijna alle gemeenten (op ongeveer 20 na) aan de wettelijke verplichting voldaan (Wildeman, 2006). De samenwerkingsmogelijkheid werd veel gebruikt. Vanaf het eerste begin werkten bijna alle provincies ${ }^{8}$ samen in rekenkamers op landsdeelniveau. In gemeenteland had in 2006 48\% van de gemeenten gekozen voor samenwerking in de vorm van een personele unie: buurgemeenten kozen ervoor om tegelijkertijd dezelfde mensen te benoemen, zodat formeel alle gemeenten hun eigen rekenkamer hadden, maar deze feitelijk als één orgaan functioneerden (Wildeman, 2006).

Die bijna volledige naleving van de rekenkamerverplichting was echter niet het hele verhaal. In de evaluatie van lokale en provinciale rekenkamers in 2011 was voor het eerst aandacht voor de zogenoemde slapende rekenkamers: inactieve rekenkamers met geen of miniem budget (Van der Mark e.a., 2011). Formeel voldoen deze aan de wet, maar materieel niet. De onderzoekers hadden geen harde cijfers, maar schatten het aantal slapende rekenkamers als 'zeer beperkt (zeker geen tientallen)' (Van der Mark e.a., 2011: 49). Deze inactiviteit werd vooral in verband gebracht met de bezuinigingsgolf vanwege de financiële crisis in die jaren. Twee jaar later zagen De Jong e.a. (2013) 35 gemeenten die tijdelijk of permanent geen actieve rekenkamer hadden, ongeveer $8,5 \%$ van alle gemeenten. Dat percentage bleef in de jaren daarna min of meer gelijk (Van der Mark \& De Wal, 2015; Van den Broek, 2020). De door BZK ingestelde Werkgroep Lokale rekenkamers meende in 2019 echter dat in 44 van de 355 gemeenten geen rekenkamer actief was; het percentage was dus inmiddels opgelopen tot ruim 12\% (Dreef e.a., 2019).

De slapende rekenkamers laten zien hoe belangrijk de randvoorwaarden zijn voor rekenkamers. In diverse onderzoeken is in de loop van de jaren aandacht besteed aan de beschikbare budgetten, waaruit rekenkamers hun onderzoeken, vergoeding voor leden en ondersteuning moeten betalen. Uit de evaluatie van de dualisering in 2007 bleek dat rekenkamers gemiddeld jaarlijks over $€ 68.000$ beschikten; variërend van $€ 20.000$ voor kleine gemeenten tot $€ 170.000$ voor gemeenten met meer dan 100.000 inwoners (Brandsen e.a., 2007). Vier jaar later was het gemiddelde budget gestegen tot ruim $€ 97.000$, wat betekende dat voor onderzoek grofweg $€ 1$ per inwoner beschikbaar was; voor kleine gemeenten was dit wat meer (gemiddeld $€ 1,47$ ), voor grote steden wat minder (gemiddeld $€ 0,70$ ) (Van der Mark e.a., 2011). In de jaren daarna daalden de budgetten sterk, onder meer door bezuinigingen als gevolg van de financiële crisis (Herweijer en Marseille, 2014). In 2019 berekende Van den Broek dat de budgetten weer waren gestegen, naar een gemiddelde van $€ 1,20$ per inwoner (Van den Broek, 2020). ${ }^{9}$

8 Op de provincie Zeeland na.

9 Meegerekend zijn de inwoners van de 323 gemeenten met een rekenkamer(commissie). 


\subsection{Model en samenstelling}

Gemeenten en provincies kunnen kiezen tussen een rekenkamer en een rekenkamerfunctie. ${ }^{10}$ Eind 2005 bleek uit de eerste overzichten dat minder dan $10 \%$ van alle gemeenten een rekenkamer had ingesteld (vooral in grotere gemeenten). Dat cijfer is door de jaren heen tamelijk constant gebleven. Daarnaast zijn er vanaf het begin vijf (samenwerkende) provinciale rekenkamers geweest.

Alle overige gemeenten kozen bij de start voor de rekenkamerfunctie, die in de praktijk bijna altijd een commissie is. In de beginjaren hadden in de meeste gemeenten raadsleden daarin zitting: soms in een rekenkamercommissie met alleen raadsleden ( $7 \%$ van de commissies), maar meestal gemengd met externe leden. Ruim de helft van de rekenkamercommissies bestond uit externe leden en raadsleden (Wildeman, 2006). In de daaropvolgende jaren nam het aantal rekenkamercommissies met raadsleden steeds meer af. In 2007 bleek uit de eerste evaluatie in opdracht van het ministerie van BZK dat ongeveer $40 \%$ van de deelnemende gemeenten een commissie met raadsleden had (al dan niet gemengd met externen), en iets minder gemeenten een commissie zonder raadsleden. $18 \%$ van de gemeenten kende een onafhankelijke rekenkamer met alleen externe leden, en $4 \%$ koos voor het zogenaamde directeursmodel, dat wil zeggen een rekenkamerfunctie met slechts één lid (Brandsen e.a., 2007). In 2015 bleek het aantal rekenkamercommissies met raadsleden nog wat te zijn teruggelopen, tot $32 \%$ van het totaal aantal deelnemende gemeenten, en vormden onafhankelijke rekenkamers en rekenkamercommissies zonder raadsleden een duidelijke meerderheid (Van der Mark \& De Wal, 2015; vgl. De Jong e.a., 2013). Die trend zette zich voort: in 2019 had een kwart van de gemeenten een rekenkamercommissie met raadsleden, en had $66 \%$ een onafhankelijke rekenkamer of rekenkamercommissie zonder raadsleden (Van den Broek, 2020).

Ongeveer dezelfde verhoudingen zien we ook terug in de door ons verzamelde gegevens. Van de 234 rekenkamer(commissie)s waarvan we rapporten hebben kunnen terugvinden, had in 2019 69\% een rekenkamercommissie met enkel externe leden of een onafhankelijke rekenkamer. In bijna een derde van de rekenkamercommissies zaten (enkel) raadsleden. In onze analyse ligt het percentage rekenkamers met raadsleden dus iets hoger dan in andere onderzoeken. ${ }^{11}$

\subsection{Positionering en politiek klimaat}

De rekenkamers opereren niet in een vacuüm, maar zijn onderdeel van een politiek-bestuurlijk krachtenveld. In hun functioneren hebben zij binnen de gemeente in ieder geval te maken met de gemeenteraad, het college en de ambtelijke organisatie (of de provinciale equivalenten daarvan).

10 De rekenkamer wordt soms ook 'onafhankelijke' rekenkamer genoemd, omdat die enkel externe leden kent.

11 Een mogelijke reden hiervoor is dat we het aantal rekenkamer(commissie)s hebben geteld in plaats van het aantal gemeenten; het komt voor dat één rekenkamer(commissie) voor meerdere gemeenten werkt. 
Dit bredere politiek-bestuurlijke krachtenveld waarin rekenkamers actief zijn, krijgt relatief weinig aandacht in eerder onderzoek. Dat betekent niet dat er niets over bekend is. Zo vroegen Brandsen e.a. (2007) en Van der Mark e.a. (2011) in hun evaluaties naar (ongevraagde) invloedsuitoefening op de rekenkamer(commissie) door de gemeenteraad en het college, dan wel provinciale staten en gedeputeerde staten. Gaf in 2007 53\% van de respondenten aan dat invloedsuitoefening voorkwam, in 2011 was volgens 18\% zelden of met enige regelmaat sprake van ongewenste invloedsuitoefening door de gemeenteraad en volgens $27 \%$ door het college. Hier lijkt dus sprake van een daling, hoewel in 2007 geen onderscheid werd gemaakt tussen gewenste en ongewenste invloeduitoefening en er gevraagd werd naar politieke beïnvloeding in het algemeen. De ongewenste invloedsuitoefening door de gemeenteraad uitte zich bijvoorbeeld door (ongewenste) bemoeienis met de onderwerpskeuze, het budget en de inhoud van onderzoek. Rekenkamers zagen ongewenste beïnvloeding door het college door bijvoorbeeld het vertragen van onderzoek of het vooruitlopen op aanbevelingen (Van der Mark e.a., 2011). Recent journalistiek onderzoek bevestigt de cijfers uit 2011: circa $20 \%$ van de rekenkamers ervaart regelmatig politieke druk (Logger e.a., 2021). De evaluatie van Van der Mark e.a. (2011) laat wel zien dat driekwart van de rekenkamers, griffiers en burgemeesters van mening is dat het politieke klimaat en verhoudingen geen impact hebben op hoe er in de gemeente met rekenkameronderzoek wordt omgegaan. Zowel de raad als het college zouden welwillend staan tegenover het werk van de rekenkamer, omdat zij een politiek neutrale speler zijn.

\section{Rekenkameronderzoek in gemeenten en provincies}

\subsection{De 'productie' van rekenkamers}

Het aantal rekenkamerrapporten dat rekenkamers produceren, ligt al sinds het ontstaan van het rekenkamerinstrument en de voorlopers daarvan op min of meer hetzelfde niveau. In de periode van 1991 tot medio 2004 brengt een rekenkamer(commissie), rekeningcommissie of evaluatiecommissie gemiddeld 1,1 rapport per jaar uit (Steiner, 2004). In de jaren daarna blijven de cijfers grofweg gelijk: gemiddeld 0,9 rapport per rekenkamer in 2005, 1,4 in 2006 en 1,0 in 2007 (Brandsen e.a., 2007). In 2011 en 2012 ronden rekenkamercommissies gemiddeld 1 tot 1,5 onderzoek per jaar af, tegenover gemiddeld circa drie onderzoeken per jaar door rekenkamers met eigen onderzoekers in dienst (De Jong e.a., 2013). Uit onze eigen analyse van rekenkamerrapporten uit 2017-2019 volgt dat de onderzochte rekenkamers elk jaar gemiddeld 1,5 rapport per gemeente uitbrengen.

Achter het gemiddelde aantal rapporten dat jaarlijks wordt uitgebracht, gaan aanzienlijke verschillen tussen rekenkamer(commissie)s schuil. Zo volgt uit de inventarisatie van Steiner (2004) dat provinciale rekenkamers gemiddeld meer onderzoeken uitbrengen dan die van gemeenten. Bovendien geldt: hoe groter de gemeente, hoe hoger de productie. Dit gegeven hangt samen met het beschikbare budget, zo is af te leiden uit latere onderzoeken. Brandsen e.a. (2007) en De Jong e.a. (2013) constateren dat rekenkamers een hogere gemiddelde productie ken- 
nen dan rekenkamercommissies. Het zijn vooral de grotere gemeenten die een rekenkamer hebben en met de gemeentegrootte neemt ook het beschikbare budget toe. Ook in onze eigen analyse zien we dat in grotere gemeenten meer rapporten worden afgerond. Amsterdam publiceerde bijvoorbeeld 22 rapporten in de jaren 2017-2019; Rotterdam en Den Haag respectievelijk 13 en 12 rapporten, ruim boven het gemiddelde dus.

Stijging van het budget leidt echter niet tot een evenredige toename in productie. De Jong e.a. (2013) zagen dat een directeursmodel met eigen onderzoekers in 2011 en 2012 gemiddeld 6,38 rapporten afrondde, met een jaarbudget van gemiddeld $€ 527.000$ in 2012. Anders gezegd: met elk onderzoek was gemiddeld $€ 165.204$ gemoeid. Bij rekenkamercommissies met enkel externe leden kostte in 2012 elk afgerond onderzoek gemiddeld $€ 32.804$ (het gemiddelde beschikbare jaarbudget van $€ 41.989$ leverde gemiddeld 2,56 rapporten op). Tegelijkertijd blijft het lastig om deze cijfers te vergelijken. De opbouw van het rekenkamerbudget is vaak onduidelijk - ambtelijke ondersteuning is bijvoorbeeld soms wel en soms niet meegenomen - en de omvang en reikwijdte van de onderzoeken kunnen sterk verschillen.

\subsection{Onderwerpen van onderzoek}

Sinds het instellen van het rekenkamerinstrument komt een aantal onderwerpen steeds terug in rekenkameronderzoek. Steiner (2004) constateert dat tussen 1991 en medio 2004 vooral veel onderzoek werd gedaan naar subsidies, inkoop en aanbesteding en de inhuur van extern personeel. Soortgelijke onderwerpen zijn terug te zien in de top vijf van meest onderzochte onderwerpen tussen 2002 en 2006: (1) grondbeleid, (2) subsidiebeleid, (3) inhuur externen, (4) kwaliteit van de programmabegroting en (5) grote bouwprojecten (Wildeman, 2006: 3). Dat zien we ook in de jaren erna (Brandsen e.a., 2007; Anderson, 2011, Hanemaayer, 2012), ondanks dat externe inhuur uit de top van meest onderzochte onderwerpen wegvalt en onderzoek naar verbonden partijen erbij komt. Wat opvalt aan deze onderwerpen is dat er sprake is van een relatief grote interne gerichtheid. In feite gaat het om aspecten die raken aan bedrijfsvoering, en niet aan inhoudelijke beleidsthema's.

Onze eigen analyse laat zien dat in de jaren 2017-2019 intern gerichte onderwerpen populair blijven, maar dat er enige verschuiving heeft plaatsgevonden naar meer inhoudelijke beleidsthema's (zie tabel 1). In 2017 was het meest onderzochte onderwerp de Wmo, gevolgd door verbonden partijen. Een jaar later stond onderzoek naar burgerparticipatie bovenaan, gevolgd door doorwerkingsonderzoek. In 2019 waren jeugdzorg (23 onderzoeken) en wederom verbonden partijen (21 onderzoeken) het meest populair. Van de elf meest onderzochte onderwerpen zijn er vijf gericht op een inhoudelijk beleidsthema en zes betreffen bedrijfsvoering. Daaronder vallen de 'klassieke' onderwerpen als verbonden partijen en financiën, maar ook nieuwere onderwerpen als informatieveiligheid. 
Tabel 1 Aantal rekenkamerrapporten per onderwerp per jaar; top 11 van meest onderzochte onderwerpen

\begin{tabular}{lcccr}
\hline Onderwerp & $\mathbf{2 0 1 7}$ & $\mathbf{2 0 1 8}$ & $\mathbf{2 0 1 9}$ & Totaal \\
\hline Wmo & 25 & 16 & 16 & 57 \\
Verbonden partijen & 22 & 13 & 21 & 56 \\
Doorwerking & 14 & 23 & 19 & 56 \\
Jeugdzorg & 13 & 18 & 23 & 54 \\
Duurzaamheid & 16 & 19 & 10 & 45 \\
Burgerparticipatie & 15 & 25 & 4 & 44 \\
Functioneren raad & 13 & 16 & 14 & 43 \\
Financiën & 18 & 10 & 7 & 35 \\
Informatieveiligheid & 13 & 9 & 13 & 35 \\
Sociaal domein & 8 & 8 & 13 & 29 \\
Veiligheid & 12 & 5 & 12 & 29 \\
\hline
\end{tabular}

\subsection{Aandacht voor doeltreffendheid, doelmatigheid en rechtmatigheid}

Een van de opdrachten aan rekenkamers is dat zij een bijdrage leveren aan de doeltreffendheid, doelmatigheid en rechtmatigheid van het bestuur. Deze drie elementen krijgen echter niet evenveel aandacht in rekenkameronderzoek. Vooral rechtmatigheid komt relatief weinig aan bod (zie ook de bijdragen van Arjan Kok en Jan van der Bij in dit themanummer). Daarentegen krijgen doeltreffendheid en doelmatigheid juist veel aandacht. In de periode 1991-medio 2004 komen doelmatigheid en doeltreffendheid gezamenlijk in 33\% van de onderzoeken aan bod, enkel doelmatigheid in $19 \%$ van de onderzoeken en enkel doeltreffendheid in $14 \%$ van de onderzoeken. Slechts in $4 \%$ van de onderzoeken komen doelmatigheid en doeltreffendheid helemaal niet terug (Steiner, 2004). Ook rekenkamers zelf geven aan dat zij het meest zijn gericht op doeltreffendheid, gevolgd door doelmatigheid (Brandsen e.a., 2007; Van der Mark e.a., 2011).

In 2007 stelt een deel van de rekenkamers zelfs dat doeltreffendheid in alle onderzoeken wordt meegenomen, hoewel $79 \%$ van de rekenkamers tegelijkertijd aangeeft in onderzoek meer aandacht te willen hebben voor de effecten van beleid (Brandsen e.a., 2007). In 2011 meldt circa 60\% van de griffiers en rekenkamers eveneens dat de effecten van beleid nog te weinig in rekenkameronderzoek terugkomen (Van der Mark e.a., 2011). Hieruit valt af te leiden dat onderzoek naar doeltreffendheid en doelmatigheid vooral gericht is op de 'output' van beleid, in plaats van de 'outcome' (maatschappelijke effecten). Hanemaayer (2012) merkt iets soortgelijks op: het rekenkameronderzoek is volgens hem vooral gericht op het proces van beleidsvorming en beleidstechniek. Gegevens over doelbereik, in de zin van gerealiseerde maatschappelijke effecten, ontbreken veelal, waardoor geen echt inzicht in doeltreffendheid en doelmatigheid wordt bereikt.

In onze analyse van rekenkamerrapporten die zijn afgerond in de periode 2017-2019, zien we ook dat doeltreffendheid in ieder geval in woorden de meeste 
aandacht krijgt, gevolgd door doelmatigheid. Van de geanalyseerde 982 onderzoeken wordt in $61 \%$ verwezen naar doeltreffendheid en in $31 \%$ naar doelmatigheid. Expliciete aandacht voor rechtmatigheid is er in $11 \%$ van de onderzoeken. Vergeleken met de periode 1991-2004 lijkt de aandacht voor doeltreffendheid en doelmatigheid dus wat te zijn teruggelopen.

Opvallend in onze analyse van rekenkamerrapporten is echter dat in ruim $33 \%$ van de rapporten de woorden doelmatig, doeltreffend of rechtmatig (of varianten ervan) niet terugkomen. Het is aannemelijk dat een deel van deze rapporten zich wel degelijk richt op deze 'fenomenen', maar dat rekenkamers het letterlijke woord niet gebruiken. We zien echter ook heel wat onderzoeksonderwerpen terug waarbij de invalshoek van doelmatigheid, doeltreffendheid en rechtmatigheid minder passend is. Denk aan onderzoeken naar de rolneming van de gemeenteraad en de mate waarin deze is toegerust om zijn taken te kunnen vervullen. In 43 onderzoeken in de periode 2017-2019 was het functioneren van de gemeenteraad het hoofdonderwerp, maar ook in andere onderzoeken is de rolneming van de raad regelmatig het centrale aandachtspunt. Zo zien we heel wat onderzoeken naar gemeenschappelijke regelingen en andere samenwerkingsverbanden, waarin de aandacht vooral uitgaat naar de manier waarop de gemeenteraad zijn kaderstellende en controlerende rol invult. Bij onderwerpen als doorwerking, politieke druk op ambtenaren en de inrichting van de begrotingscyclus zijn doelmatigheid, doeltreffendheid en rechtmatigheid eveneens minder relevant.

\subsection{Gehanteerde onderzoeksmethoden}

Ook de vraag hoe rekenkamers hun onderzoek inrichten, is relevant. Met andere woorden: welke onderzoeksmethoden worden ingezet? Schilder e.a. (2021) laten in dit themanummer zien dat in de 109 door hen onderzochte rapporten documenten- en dossieronderzoek in nagenoeg elk rapport terugkomt. In driekwart van de rapporten wordt documenten- en dossieronderzoek aangevuld met interviews. Slechts in $7 \%$ van de rapporten worden (ook) andere methoden toegepast.

In onze eigen analyse van 982 rekenkamerrapporten uit 2017, 2018 en 2019 zien we eveneens de dominantie van documenten- en dossieronderzoek en interviews terug. Het analyseren van documenten en dossiers lijkt daarbij een basismethode: in $97 \%$ van de onderzoeken wordt verwezen naar documenten, deskresearch of een combinatie ervan. Ook interviews blijken onlosmakelijk verbonden met rekenkameronderzoek: in $89 \%$ van de onderzoeken is gebruikgemaakt van interviews, al dan niet in de vorm van groepsgesprekken. De derde relatief vaak gehanteerde methode is het uitzetten van een enquête; deze methode zien we in $12 \%$ van de onderzoeken terug. In $37 \%$ van de geanalyseerde onderzoeken zien we echter dat rekenkamers andere of aanvullende methoden inzetten. Denk aan het uitvoeren van een benchmark (48 onderzoeken), meelopen in de beleidspraktijk (23), observaties (10), 'mystery guest'-onderzoek (12) of zelfs een rollenspel (1). 


\section{De bijdrage van rekenkameronderzoek: wat weten we hierover?}

\subsection{Bijdrage aan de kaderstellende en controlerende functie van de volksvertegen- woordiging}

Zoals gezegd is de kennis over de bijdrage die rekenkamers leveren aan het decentraal bestuur beperkt, maar er is wel degelijk enig onderzoek naar gedaan. In diverse rapporten is aandacht besteed aan de vraag of rekenkamers en hun onderzoeken bijdragen aan de versterking van het werk van gemeenteraden, in het bijzonder de kaderstelling en controle. Dit wordt altijd gemeten door het in enquêtes te vragen aan betrokkenen, wat betekent dat de gegevens hierover subjectief zijn.

Uit de evaluatie van het rekenkamerinstrument voor gemeenten en provincies in 2007 blijkt dat de overgrote meerderheid (82\%) van de ondervraagde rekenkamers, griffiers en secretarissen van mening is dat de rekenkamer de controlerende functie van raad of staten versterkt (Brandsen e.a., 2007). Onderzoek uit 2010 bevestigt de tevredenheid van decentrale rekenkamers zelf: zij geven zichzelf een gemiddelde 7,0 waar het hun bijdrage aan de controlerende rol van de raad en staten betreft, en een 6,4 voor wat betreft de kaderstelling. Rekenkamerleden zijn daarnaast tevreden over de mate waarin hun aanbevelingen worden overgenomen en worden doorgevoerd (Van der Zee \& De Jong, 2010). De onderzoekers presenteren ook gegevens van de zogenoemde Quick Scan Lokaal Bestuur, waaruit blijkt dat $84 \%$ van de raadsleden uit 54 onderzochte gemeenten tevreden tot zeer tevreden is over hun rekenkamer. Ook griffiers (77\%), ambtenaren (73\%) en collegeleden (69\%) denken er zo over (Van der Zee \& De Jong, 2010).

De evaluatie uit 2011 laat opnieuw zien dat rekenkamers en griffiers in overweldigende mate (respectievelijk $94 \%$ en $82 \%$ ) vinden dat de rekenkameronderzoeken de controlerende rol van raden en staten hebben versterkt; burgemeesters zijn met 54\% wat minder overtuigd (Van der Mark e.a., 2011). De onderzoekers concluderen mede op basis hiervan 'dat de controlerende functie van de raad/provinciale staten versterkt is' (p. 2). Tegelijkertijd stellen de onderzoekers vast dat alle respondenten het erover eens zijn dat de onderzoeken niet leiden tot versterking van de controlemechanismen in de volksvertegenwoordiging in meer algemene zin. Zo gebruiken raden en staten volgens de bestuurders, nagenoeg alle raads- en statenleden en de meeste rekenkamervoorzitters de onderzoeksuitkomsten niet om meer en scherpere vragen aan het college te stellen en leggen zij geen parallellen met andere dossiers (Van der Mark e.a., 2011). Voor wat betreft de bijdrage van rekenkamers aan de kaderstellende rol concludeert de evaluatie dat deze rol sinds de dualisering volgens alle betrokkenen sowieso nog niet goed uit de verf komt en rekenkamers er dus ook niet veel aan kunnen bijdragen.

Recenter onderzoek bevestigt het eerdere beeld dat raadsleden in ruime mate tevreden zijn over het instrument rekenkamer: in 2015 is driekwart van de raadsleden tevreden over het rekenkamerinstrument en vindt $47 \%$ dat de rol van de raad is versterkt door het werk van de rekenkamer (Van der Mark \& De Wal, 
2015); gevraagd naar de meest gewaardeerde 'hulptroepen' zetten raadsleden in 2017 de rekenkamer op nummer één (Schram e.a., 2017: 20). Minder positief zijn Peters en Castenmiller (2020). Op basis van kwalitatieve gesprekken met raadsleden in tien gemeenten stellen zij vast dat de aanbevelingen van rekenkameronderzoeken weliswaar meestal door de raden worden overgenomen, maar dat de meningen onder raadsleden over de bruikbaarheid ervan uiteenlopen en dat de uitvoering van aanbevelingen in diverse gemeenten niet (goed) wordt gemonitord. In diverse gemeenten geven raadsleden desgevraagd aan zelden of nooit gebruik te maken van de rapporten voor de controle van het bestuur. Ook in gemeenten waar de rekenkamer een vrij sterke aanwezigheid kent, vinden de meeste gesprekspartners (raadsleden, griffiers, bestuurders, ambtenaren) dat er op dit punt zeker verbetering mogelijk is (Peters \& Castenmiller, 2020).

\subsection{Bijdrage aan publieke verantwoording}

In paragraaf 2 onderscheidden we de beoogde bijdrage van rekenkamers aan de publieke verantwoording naar burgers en samenleving. Ons is geen wetenschappelijk onderzoek hiernaar bekend, met één uitzondering. Van der Zee en De Jong vroegen in 2010 aan rekenkamers of zij bijdroegen aan het afleggen van rekenschap aan burgers. De 101 rekenkamervertegenwoordigers waren daar minder positief over dan over andere vormen van meerwaarde: zij gaven zichzelf een gemiddelde 5,8 hiervoor.

\subsection{Bijdrage aan doeltreffendheid, doelmatigheid en rechtmatigheid}

Het derde doel van rekenkameronderzoek (zie paragraaf 2 ) is de bijdrage aan (de verbetering van) de doeltreffendheid, doelmatigheid en rechtmatigheid van het bestuur. In de vakliteratuur is in de loop van de jaren relatief veel geschreven over de diverse vormen of typen van 'doorwerking' van rekenkameronderzoek, een term afkomstig uit de literatuur over de wijze waarop kennis en (beleids)advies doorwerken in het beleid (Bekkers e.a., 2004; Hoekstra, 2013; Lemmens, 2014; Gerritsen \& Lemmens, 2017). Rekenkamers onderzoeken zelf ook regelmatig de doorwerking van hun eigen rapporten. In dit themanummer neemt Sjoerd Keulen een aantal van dergelijke doorwerkingsonderzoeken als basis voor een analyse hoe (een gebrek aan) doorwerking kan worden verklaard. Betrouwbare gegevens over de mate waarin rekenkameronderzoek bijdraagt aan de doeltreffendheid en doelmatigheid van het gemeentebestuur in het algemeen, kunnen we aan deze 'zelfevaluaties' echter niet ontlenen.

De evaluatie van lokale en provinciale rekenkamers uit 2011 is een van de weinige bronnen voor gegevens over de mate van doorwerking of effectiviteit van rekenkamers (Van der Mark e.a., 2011). Voor wat betreft de 'instrumentele doorwerking' (ofwel 'directe doorwerking') wordt geconcludeerd dat nagenoeg alle rekenkamers en griffiers van mening zijn dat aanbevelingen van rekenkameronderzoek meestal of altijd worden overgenomen door de volksvertegenwoordiging. Volgens $79 \%$ nemen ook de colleges de aanbevelingen meestal of altijd over (Van der Mark e.a., 2011). Het is echter onduidelijk wat 'overnemen' in de vraagstelling betekent en of het dan ook om daadwerkelijk 'uitvoeren' gaat. Bovendien is het een subjec- 
tieve inschatting van de rekenkamervoorzitters en griffiers die de enquête hebben ingevuld.

De evaluatie uit 2011 kijkt ook naar 'conceptuele doorwerking' in de zin van meer aandacht voor doeltreffendheid en doelmatigheid in de ambtelijke organisatie. Daarover blijken de meningen uiteen te lopen: de rekenkamers denken dat de aandacht voor doelmatigheid en doeltreffendheid alleen al door de aanwezigheid van de rekenkamer(commissie) is gegroeid, maar de bestuurders en ambtenaren bestrijden deze visie en denken dat andere ontwikkelingen zoals de introductie van de programmabegroting veel sterker hebben bijgedragen aan de grotere aandacht bij het bestuur voor doelmatigheid en doeltreffendheid (Van der Mark e.a., 2011).

Dat overnemen en daadwerkelijk uitvoeren van aanbevelingen twee verschillende dingen zijn, volgt uit onderzoek van Anderson (2011). Uit een analyse van 63 rekenkamerrapporten in 21 gemeenten bleek dat slechts $28 \%$ van de aanbevelingen die de gemeenteraden hadden aangenomen, geheel of gedeeltelijk bleek te zijn doorgevoerd. Anderson wijst erop dat het ambtelijk management, het college en de rekenkamer van de onderzochte gemeenten zelf inschatten dat respectievelijk $73 \%$, $66 \%$ en $55 \%$ van de aanbevelingen waren doorgevoerd. Dat is een zeer afwijkend beeld dus. Als oorzaken voor het gebrek aan effectiviteit noemt Anderson naast gebrek aan budget of capaciteit ook ambtelijke weerstand tegen de aanbevelingen. Hij concludeert verder dat aan de raad niet altijd correct werd gerapporteerd over het niet uitvoeren van aanbevelingen (Anderson, 2011).

Hoe moeilijk het is om doorwerking te onderzoeken, blijkt ook uit een latere evaluatie. Daarin zijn de griffiers in een enquête bevraagd over onder meer de doorwerking (Van der Mark \& De Wal, 2015). In de enquête wordt een volgens ons verwarrend onderscheid gemaakt tussen 'de doorwerking van de uitkomsten uit de eindproducten van de rekenkamer(commissie)' en 'de implementatie van de aanbevelingen uit de eindproducten van de rekenkamer(commissie)'. De tevredenheidsscores van de griffiers voor beide aspecten zijn overigens bijna identiek: de grote meerderheid is (enigszins) tevreden over beide zaken. Opvallend is verder dat in dit onderzoek de griffiers hebben geantwoord namens hun raad en college. Volgens de griffiers zijn ook de raadsleden in grote meerderheid (enigszins) tevreden over de doorwerking. Voor het college ligt dat percentage wat lager (ongeveer een kwart), maar daar kon of wilde een aanzienlijk deel van de griffiers zich niet over uitspreken (Van der Mark \& De Wal, 2015).

\section{Conclusies en vervolgvragen}

In dit artikel stond de vraag centraal welke kennis beschikbaar is over decentrale rekenkamers, in het bijzonder over de bijdrage die het instrument levert aan het werk van de gemeenteraad en provinciale staten. De ontstaansgeschiedenis en ontwikkeling van het rekenkamerinstrument laten zien dat het beoogde doel van het instrument primair was om bij te dragen aan een doelmatiger, doeltreffender 
en rechtmatiger bestuur en aan het versterken van de kaderstellende en controlerende rol van de gemeenteraad of provinciale staten. De vraag of en in hoeverre dat rekenkamers lukt, levert een gemengd antwoord op.

We zien dat rekenkamers zich in het overgrote deel van de gemeenten en in alle provincies een plek hebben verworven. Verreweg de meeste gemeenten hebben gekozen voor een rekenkamerfunctie, maar het aandeel gemeenten dat daarbij kiest voor een model met enkel externe leden, is sinds de introductie van het rekenkamerinstrument toegenomen en komt nu veruit het meeste voor. Desondanks heeft nog steeds ongeveer een kwart tot een derde van de rekenkamercommissies (ook) interne leden. Dat verandert in één klap als later dit jaar het parlement zou instemmen met de voorgestelde wijziging van de Gemeentewet die een onafhankelijke rekenkamer verplicht stelt voor alle gemeenten.

De bijdrage die rekenkamers leveren in termen van kwantitatieve output, is sinds hun introductie licht toegenomen van circa 1 onderzoek naar gemiddeld 1,5 onderzoek per jaar. Rekenkamers van grotere gemeenten - met meer budget hebben in de regel een hogere gemiddelde productie en besteden gemiddeld ook meer per onderzoek. De budgetten zijn in de loop van de tijd gevoelig gebleken voor de economische conjunctuur en na een initiële toename van budgetten is er in de jaren na de financiële crisis aanzienlijk op bezuinigd. Het is dan ook niet verrassend dat de gemiddelde productie van rekenkamer(commissie)s al met al nauwelijks is toegenomen. De constatering roept ook vragen op voor de toekomst: wat zal de huidige zorgwekkende financiële situatie van veel gemeenten gaan betekenen voor de rekenkamerbudgetten?

De eerste jaren na de invoering van het rekenkamerinstrument waren de onderzoeken vooral gericht op bedrijfsvoering. Denk aan onderzoek naar subsidieverlening, kwaliteit van de begroting en de inhuur van externen. Dit zijn nog steeds thema's die veel worden onderzocht, maar er heeft wel enige verbreding plaatsgevonden. Er is meer aandacht voor de doelmatigheid en doeltreffendheid van het gevoerde beleid, bijvoorbeeld in het sociaal domein of op het gebied van duurzaamheid.

Potentieel leveren rekenkamers daarmee enige bijdrage aan de doelmatigheid, doeltreffendheid en rechtmatigheid van het gevoerde bestuur, maar we hebben geen goed zicht op het effect van de onderzoeken op de kwaliteit van het bestuur. De aanbevelingen die rekenkamers op basis van het onderzoek formuleren, worden veelal overgenomen door de gemeenteraad, en gemeenteraadsleden zijn dan ook behoorlijk tevreden over hun rekenkamer(commissie). Maar of en in welke mate de aanbevelingen ook tot daadwerkelijke verbetering van het bestuur leiden, is niet goed duidelijk. Direct betrokkenen zoals rekenkamers en volksvertegenwoordigers zijn begrijpelijkerwijs geneigd die impact positief in te schatten, maar er zijn aanwijzingen dat de werkelijkheid minder rooskleurig is.

Als het gaat om de bijdrage van rekenkamers aan de versterking van kaderstelling en controle door gemeenteraden en provinciale staten, dan valt op dat het reken- 
kameronderzoek veelal is gericht op de beleidsuitvoering en niet zozeer op het meten van de maatschappelijke effecten. Uit de evaluaties van het rekenkamerinstrument door de jaren heen blijkt dat rekenkamers en raads- en statenleden zelf vinden dat de rekenkamer zeker bijdraagt aan de versterking van de controlerende taak van raden en staten. Maar of dat daadwerkelijk ook zo is, weten we eigenlijk niet. Er zijn ook signalen dat rekenkameronderzoeken niet veel worden gebruikt voor het bevragen van het college en niet leiden tot versterking van de controlemechanismen in meer algemene zin. Qua kaderstelling door volksvertegenwoordigers is het beeld niet scherp, mede omdat er over die rol sowieso onduidelijkheid bestaat bij betrokkenen in het lokaal en provinciaal bestuur.

Rekenkamers zouden ten slotte moeten bijdragen aan de bredere publieke verantwoording richting burgers, maar daarover weten we te weinig. De openbare rapporten bieden de buitenwereld zeker de mogelijkheid om zicht te krijgen op het gevoerde bestuur, maar met gemiddeld 1,5 rekenkameronderzoek per gemeente per jaar is dat op zijn best slechts een begin. Het is dan ook ten aanzien van deze thema's dat toekomstig onderzoek nodig is, zodat gericht gewerkt kan worden aan het toekomstbestendig maken van het rekenkamerinstrument voor de komende twintig jaar.

\section{Literatuur}

Anderson, R., 'Het rekenkamereffect', ControllersMagazine, 2011/10.

Bakker, N., P.G. Castenmiller \& B. Smallenbroek, De alledaagse praktijk van het lokaal bestuur, Onderzoeksbijlage bij Staatscommissie Dualisme en Lokale Democratie, Den Haag: 2000.

Bekkers, V.J.J.M., H.J.M. Fenger, V.M.F. Homburg \& K. Putters, Doorwerking van strategische beleidsadvisering, Rotterdam: 2004.

Bovens, M.A.P., T. Schillemans \& P. 't Hart, 'Does public accountability work? An assessment tool', Public Administration, 2008/1, p. 225-242.

Brandsen, T., P. Kalders, L. Schaap \& R. Schouten, Leren afrekenen. Een voorlopige evaluatie van lokale en provinciale rekenkamer(commissie)s, Den Haag: 2007.

Brandsen, T., P. Kalders \& L. Schaap, 'Leren afrekenen. Verslag van een voorlopige evaluatie van lokale rekenkamer(commissie)s', Bestuurswetenschappen, 2008/5, p. 1-15.

Broek, H. van den, Zicht op rekenkamers. Onderzoek verricht in opdracht van het ministerie van Binnenlandse Zaken en Koninkrijksrelaties, Utrecht: oktober 2020.

Castenmiller, P.G. \& H. Albeda, 'Naar een activistische rekenkamer', Bestuurswetenschappen, 2009/1, p. 67-77.

Castenmiller, P.G. \& K. Peters, 'Relatie tussen rekenkamer en gemeenteraad', Openbaar Bestuur, 2011/10, p. 2-5.

Denters, S.A.H., H. van der Kolk, E. Birkenhäger, H.M. de Jong, M. Loots \& R. Noppe, Aan het hoofd der gemeente staat..., Onderzoeksbijlage bij Staatscommissie Dualisme en Lokale Democratie, Alphen aan den Rijn: 2000.

Dreef, S., H. Wesseling \& T. Scholthof, Werkgroep Lokale rekenkamers. De stand van zaken m.b.t. lokale rekenkamers, op basis van een landelijke gespreksronde, Utrecht: 2019.

Gerritsen, M. \& E. Lemmens, 'Hoe effectief is de rekenkamer?', Tijdschrift voor Public Governance, Audit and Control (TPC), 2017/4, p. 20-23. 
Hanemaayer, D., 'Onderzoek door lokale rekenkamers. Maatschappelijke effecten versus beleidstechniek', Beleidsonderzoek Online, april 2012.

Herweijer, M. \& A.T. Marseille, 'Waardering voor horizontaal toezicht', H.B. Winter, A. Tollenaar \& A.T. Marseille (eds.), Ridderorde. Beschouwingen over bestuurlijke organisatie, toezicht en juridisering, Oisterwijk: 2014, p. 47-58.

Hoekstra, R., 'Wat is de meerwaarde van onze rekenkamer? Introductie van een model om de doorwerking van rekenkameronderzoek te meten', Beleidsonderzoek Online, oktober 2013.

Jarvis, M.D., 'The black box of bureaucracy. Interrogating accountability in the public service', Australian Journal of Public Administration, 2014/4, p. 450-466.

Jong, P.O. de, J.R. Lunsing, E. Fogl \& F. Haven, De staat van de rekenkamer. Een onderzoek naar institutionele vormgeving, budget en output van gemeentelijke rekenkamers en rekenkamerscommissies, Kommerzijl: 2013.

Knaap, P. van der, V. Pattyn \& D. Hanemaayer, Beleidsevaluatie in theorie en praktijk, Den Haag: 2020.

Koster, P. \& A. Tollenaar, 'Raadsleden in lokale rekenkamers. De gevolgen voor de doorwerking van rekenkameronderzoek', Bestuurswetenschappen, 2017/1, p. 40-53.

Lemmens, E., 'Voorwerking, werking en doorwerking: Een praktisch instrument voor het meten van het effect van rekenkamers', Beleidsonderzoek Online, februari 2014.

Logger, B., H. den Boer \& P. Weijnen, 'Politieke druk op lokale rekenkamers', Binnenlands Bestuur, 2021/3, p. 14-16.

Mark, R. van der, A. Oostdijk, R. Beerepoot \& H. Heins, Evaluatie van de provinciale en gemeentelijke rekenkamers, Utrecht: 2011.

Mark, R. van der \& W. de Wal, Onderzoek naar budgetten en samenwerking van gemeentelijke rekenkamers en rekenkamercommissies, Utrecht: 2015.

Montfort, C.J. van, 'Lokale rekenkamers. Waarde door meerwaarde', Bestuurskunde, 2003/1, p. 41-49.

Peters, K. \& P.G. Castenmiller, 'Kaderstellen en controleren door de gemeenteraad. Een zware opgave', Bestuurswetenschappen, 2020/2, p. 10-32.

Schram, J., M.J.W. van Twist \& M.A. van der Steen, Raad en hulptroepen. Hefbomen ter versterking van de controlerende taak van de gemeenteraad, Den Haag: 2017.

Smink, J., 'Gebrekkige evaluatie van rekenkamers', Bestuurswetenschappen, 2008/3, p. 84-90.

Staatscommissie Dualisme en lokale democratie, Dualisme en lokale democratie, Den Haag: 2000.

Steiner, B., Inventarisatie van onderzoek door gemeentelijke en provinciale rekenkamer(functie)s, rekeningcommissies \& evaluatiecommissies van 1991 tot medio 2004, Den Haag: 2004.

Wildeman, G., 'Lokale rekenkamers. The proof of the pudding is in the eating', Tijdschrift voor Public Governance, Audit and Control (TPC), 2006/2, p. 32-36.

Zee, T. van der \& E. de Jong, Een spiegel van het lokale rekenkamerlandschap, Byond, Groningen: 2010. 